\title{
Challenge of diagnosing acute infections in poor resource
}

\section{settings in Africa [version 1; peer review: 1 approved with}

\section{reservations]}

\section{Farisai Chidzwondo (D1,2, Francisca Mutapi ${ }^{3,4}$}

\author{
${ }^{1}$ Department of Biotechnology and Biochemistry, University of Zimbabwe, Harare, 00263, Zimbabwe \\ ${ }^{2}$ TIBA Zimbabwe, NIHR Global Health Research Unit Tackling Infections to Benefit Africa (TIBA), Harare, 00263, Zimbabwe \\ 3Institute of Immunology and Infection Research, University of Edinburgh, Edinburgh, EH9 3FL, UK \\ ${ }^{4}$ Global Health Research Unit Tackling Infections to Benefit Africa (TIBA), University of Edinburgh, Edinburgh, EH9 3FL, UK
}

V1 First published: 07 Jun 2021, 4:28

https://doi.org/10.12688/aasopenres.13234.1

Latest published: 07 Jun 2021, 4:28

https://doi.org/10.12688/aasopenres.13234.1

\section{Open Peer Review}

Approval Status?

1

version 1 ?

07 Jun 2021 view

1. Randal J. Schoepp, United States Army

Medical Research Institute of Infectious

Diseases, Frederick, USA

Any reports and responses or comments on the article can be found at the end of the article. 


 (COVID-19) collection.}

Corresponding author: Farisai Chidzwondo (farisaichidzwondo@yahoo.com)

Author roles: Chidzwondo F: Conceptualization, Funding Acquisition, Visualization, Writing - Original Draft Preparation, Writing Review \& Editing; Mutapi F: Conceptualization, Funding Acquisition, Visualization, Writing - Review \& Editing

Competing interests: No competing interests were disclosed.

Grant information: This research was commissioned by the National Institute for Health Research (NIHR) Global Health Research Programme (16/136/33) using UK aid from the UK Government. F. Mutapi is a fellow of the African Academy of Sciences.

The funders had no role in study design, data collection and analysis, decision to publish, or preparation of the manuscript.

Copyright: ๑ 2021 Chidzwondo F and Mutapi F. This is an open access article distributed under the terms of the Creative Commons Attribution License, which permits unrestricted use, distribution, and reproduction in any medium, provided the original work is properly cited.

How to cite this article: Chidzwondo F and Mutapi F. Challenge of diagnosing acute infections in poor resource settings in Africa [version 1; peer review: 1 approved with reservations] AAS Open Research 2021, 4:28 https://doi.org/10.12688/aasopenres.13234.1

First published: 07 Jun 2021, 4:28 https://doi.org/10.12688/aasopenres.13234.1 


\section{Introduction}

Africa experiences a large burden of acute infectious diseases which include epidemic viral diseases such as Ebola ${ }^{1,2}$, endemic diseases, such as those caused by Plasmodium species $^{3,4}$, and recurrent water-borne bacterial diseases such as cholera ${ }^{5,6}$. The impact of these diseases is exacerbated by weak health systems and lack of rapid intervention tools. Rapid and timely diagnosis of such infectious diseases is critical for immediate patient isolation and appropriate treatment to reduce transmission, mortality and morbidity ${ }^{1,7-9}$. Consequently, there is a need for a concerted effort to develop rapid point-of-care diagnostic tools ${ }^{10-12}$ for the effective surveillance, intervention and control of such acute infections to contribute to the long term health security of the African continent.

In the first quarter of 2020 alone, the regional World Health Organization office in Africa reported 17 disease outbreaks in more than 15 member countries, in addition to the coronavirus disease 2019 (COVID-19) which was confirmed in 45 out of 47 countries $^{13}$. These infections, mainly viral, are summarized in Table 1. While the number and type of disease oubreaks are highly time-dependent, the Table shows the extent to which African continent is susceptible to infections.

These infections reduce life expectancy, lessen the quality of life and slow down economic development ${ }^{14,15}$. The vulnerability of populations to new and emerging pathogens or pathogens that have extended their geographic range, such as the Ebola and Zika viruses, is often underestimated ${ }^{2}$. For some infections, such as influenza ${ }^{16}$ and human immunodeficiency virus type $1(\mathrm{HIV}-1)^{17}$, delays in treatment not only determine the health outcome of the infected individual but the extent of transmission of the pathogen in the population as well.

Depending on the type of infection, symptoms can include pain, fever, raised temperature, high pulse, abnormally rapid breathing, nausea, anxiety and confusion. These symptoms, together with the specific geographic region in the country, can be used to inform diagnostic testing. For example, an acute febrile illness which is often a hallmark sign for malaria in rural

Table 1. Disease outbreaks reported by the Regional World Health Organization office in Africa in the first quarter of 2020.

\begin{tabular}{|c|c|c|c|}
\hline $\begin{array}{l}\text { Type of } \\
\text { Pathogen }\end{array}$ & Name of Pathogen & Disease & Countries Affected \\
\hline \multirow[t]{4}{*}{ Bacterium } & Bacillus anthracis & Anthrax & Zimbabwe \\
\hline & Yersnia pestis & Bubonic plague & The Democratic Republic of the Congo \\
\hline & Vibrio cholerae & Cholera & $\begin{array}{l}\text { Burundi; Cameroon; Ethiopia; Kenya; Malawi; Mozambique; } \\
\text { Nigeria; The Democratic Republic of the Congo }\end{array}$ \\
\hline & Neisseria meningitidis & Meningococcal meningitis & Benin \\
\hline \multirow[t]{11}{*}{ Virus } & Chikungunya virus & Chikungunya fever & Congo; Ethiopia; Kenya \\
\hline & Nairovirus & $\begin{array}{l}\text { Crimean-Congo } \\
\text { haemorrhagic fever }\end{array}$ & Mali; Uganda \\
\hline & Dengue virus & Dengue fever & Benin; Ethiopia; Mali; Senegal \\
\hline & Ebola virus & Ebola virus disease & The Democratic Republic of the Congo \\
\hline & Hepatitis E virus & Hepatitis E & Namibia; South Sudan \\
\hline & Lassa virus & Lassa fever & Liberia; Nigeria; Sierra Lione \\
\hline & Morbillivirus & Measles & $\begin{array}{l}\text { Cameroon; Central African Republic; Chad; Comoros; Ethiopia; } \\
\text { Guinea; Kenya; Lesotho; Liberia; Mali; Niger; Nigeria; Seychelles; } \\
\text { South Sudan; The Democratic Republic of the Congo }\end{array}$ \\
\hline & Monkeypox virus & Monkeypox & Cameron; Nigeria; The Democratic Republic of the Congo \\
\hline & Poliovirus & Poliomyelitis & $\begin{array}{l}\text { Angola; Benin; Cameroon; Central African Republic; Chad; Cote } \\
\text { d'Ivoire; Ethiopia; Ghana; Nigeria; The Democratic Republic of the } \\
\text { Congo; Togo; Zambia }\end{array}$ \\
\hline & Rift Valley fever virus & Rift Valley fever & Uganda \\
\hline & Yellow fever virus & Yellow fever & Ethiopia; Mali; Nigeria; Uganda; South Sudan \\
\hline \multirow[t]{2}{*}{ Protozoan } & Leishmania & Leishmaniasis & Kenya \\
\hline & Plasmodium & Malaria & Burundi \\
\hline
\end{tabular}


settings ${ }^{18}$, can be caused by several pathogens including Leishmania species, the Dengue virus, acute HIV infection, Salmonella enterica serovar Typhi and bacterial zoonoses such as Brucella and Rickettsia species ${ }^{19-21}$. Pathogens with overlapping clinical presentation such as Plasmodium parasites, Lassa and Ebola viruses often lead to misdiagnosis ${ }^{1}$ due to the paucity of appropriate diagnostic tools at primary health centres $^{19-24}$. Some infectious agents such as the Zika, Dengue and Chikungunya viruses share vectors, geographic distribution and symptoms following infection ${ }^{12,25}$ making coinfection highly possible. Such co-infections do occur due to both the persistence of old and the emergence of new infectious agents ${ }^{26,27}$. In many regions of Africa, recurrent infections occur concurrently with endemic infections such as HIV-1, Mycobacterium tuberculosis (TB) and Plasmodium falciparum (malaria). These co-infections make diagnosis difficult as the pathogens may act independently or interact with each other within the host ${ }^{19,28}$. For instance, TB and HIV co-infection, may change the clinical presentation of $\mathrm{TB}$ and reduce the sensitivity of conventional microbiology tests ${ }^{8,26}$. Simultaneous diagnosis of multiple pathogens would be appropriate for regions with high probabilities of co-infections.

Often, a lack of sensitive tests ${ }^{19,20}$ and the fear of mortality from delayed treatment, particularly in children, lead to the wide use of broad-spectrum antibiotics ${ }^{29}$. Additional testing, which increases costs and delays treatment, may be required to confidently identify a pathogen that may have tested negative with an initial diagnostic test $\mathrm{t}^{23}$. An accurate diagnosis for a pathogen is not only essential to inform appropriate patient care and treatment. It is also essential for reducing drug-related adverse effects and reducing unnecessary medical $\operatorname{costs}^{23,30}$. In the case of antibiotics, an accurate diagnosis also leads to a reduction of the over-prescription of antibiotics as well as inappropriate prescription of antibiotics in viral infections both of which are contributing to the accelerated development of antibiotic resistance $\mathrm{e}^{16,31-33}$.

Ultimately, the choice of method of diagnosis depends on the aim of the diagnosis; treating an infected patient, containing an epidemic where infection transmission can occur during the asymptomatic stage before the patient shows clinical symptoms or screening for routine surveillance. While qualitative detection of the pathogen will suffice for screening purposes, quantitative detection is required for treating infected patients and for containing epidemics.

Traditional methods of detecting infectious agents Infectious diseases are caused by agents that comprise viruses, bacteria, fungi, protozoa, helminths and arthropods. Several methods, which include microscopy, culture-based procedures, biochemical-based techniques, immunodiagnostic assays and nucleic acid-based approaches are available for the detection and identification of pathogens. These methods are either morphology-based such as microscopy or functional-based such as the immunodiagnostic assays. Any given method used for the distinctive identification of the pathogen has benefits and limitations, as summarized in Table 2. The method of choice depends on the type of infectious agent, the aim and urgency of the diagnosis and the clinical setting.

\section{Rapid diagnostic tests}

A rapid diagnostic test is a medical, visually indicative test that is quick, and simple to perform and interpret ${ }^{21,34}$. Examples of these tests include single-step lateral flow assays in the form of a dipstick or a cassette and latex agglutination kits ${ }^{21}$. Such tests usually take less than an hour to obtain results, require little or no processing and are therefore suitable for preliminary or emergency medical screening and may be used in areas with resource-limited medical settings ${ }^{12,32}$. To facilitate uptake in remote areas, rapid diagnostic tests must be portable, of low cost, stable under extreme conditions, culturally acceptable, accurate and without the need of specially trained personnel ${ }^{12}$. Where previously a diagnosis could only be performed in a laboratory, it would now be feasible through self-testing or point-of-care testing in primary health care can $^{32,34}$.

Qualitative or semi-quantitative in-vitro medical devices that involve non-automated procedures have been designed to give results quickly. Qualitatively, checks that include the malaria antigen cassette and the HIV antibody dipstick test can be used for pre-screening to confirm the presence of the target pathogen in the doctor's room or an isolated area to select probable cases before more time-consuming laboratory analysis. The semi-quantitative analysis, such as the one based on rapid influenza polymerase chain reaction (PCR) testing, indicates the concentration levels of the pathogen to assess disease status, progression, or ongoing management of the disease ${ }^{16}$. Diagnostic devices can be used singly or in series. Most diagnostic tests are protein-, carbohydrate- or nucleic acid-based as the detection of the presence of the pathogen's proteins, polysaccharides, glycoproteins, glycolipids or nucleic acids is taken as evidence of infection.

While protein-based and carbohydrate-based detection methods have been more customary in the field and resourceconstrained settings, the limitations concerning speed, sensitivity and/or specificity of each diagnostic test need to be taken into consideration when deciding which test to use. For instance, in the protein-based diagnosis of Dengue, the type 1 non-structural protein (NS1) is highly specific and detectable in serum from the first day after fever onset, whereas the sensitivity of specific IgM increases after the first few days ${ }^{12,21}$. For Leptospirosis, despite the low sensitivity, PCR-based methods are more useful for early diagnosis than the gold standard protein-based microscopic agglutination test ${ }^{35}$.

In the current COVID-19 pandemic, to accurately use PCR for diagnosis of severe acute respiratory syndrome coronavirus 2 (SARS-CoV-2), validation on the functionality of primers and probes is required. Besides, external and internal controls are needed to check for potential contaminants. For serological assays, both positive and negative sera are required to develop the tests. Consequently, in addition to scientific issues, operational issues also need to be considered in the development of a rapid diagnostic test.

Rapid protein-based and/or carbohydrate-based diagnostic tests. The majority of protein- and carbohydrate-based tests depend on the specificity of the antigen-antibody interaction and 


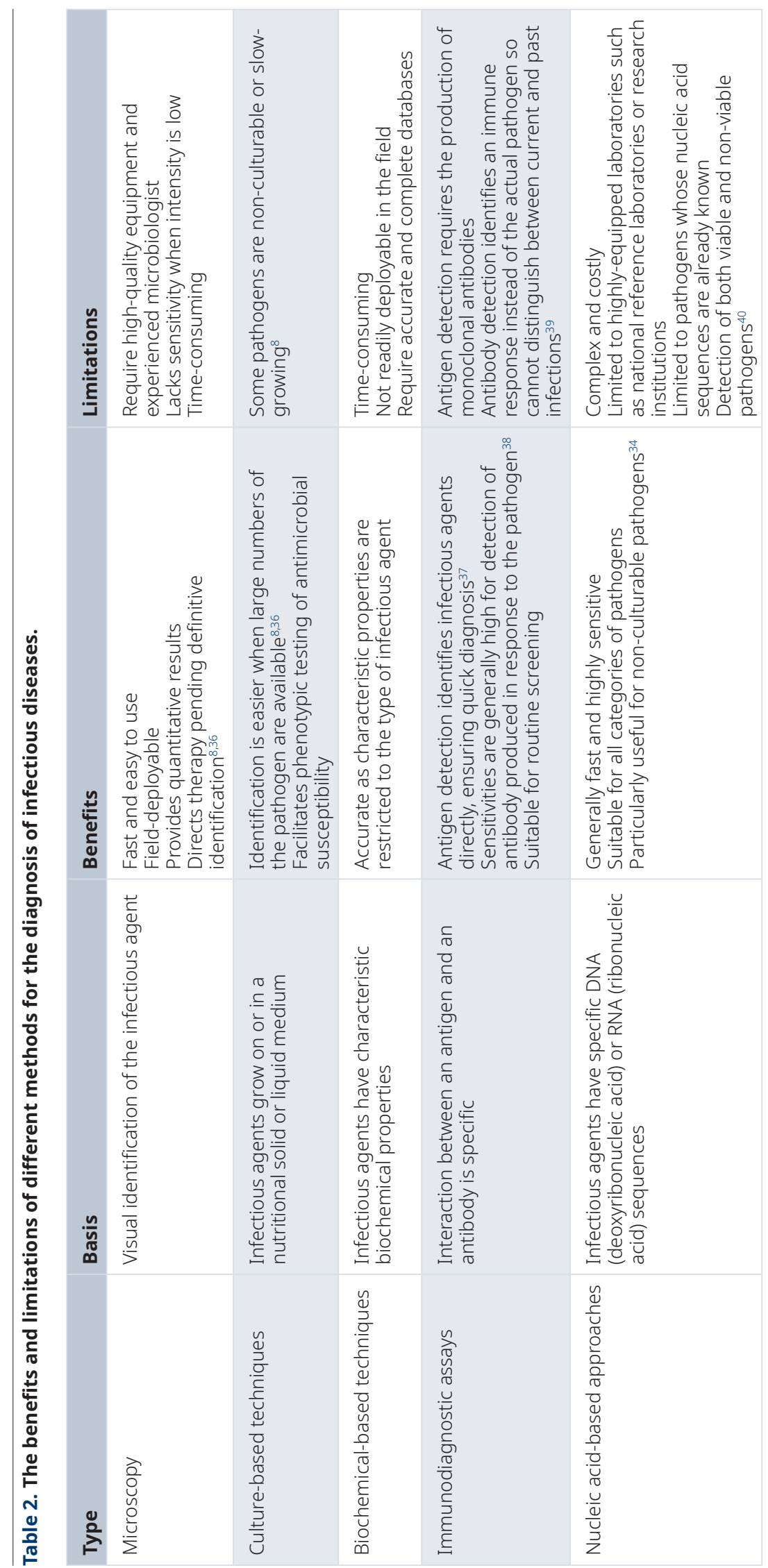


detect the presence of the antigen or the antibody in the specimen ${ }^{41}$. Despite the difficulty of generating selective antibodies, for acute infections, antigen-based tests are preferred as they detect the actual presence or absence of a bacterial, viral or parasite-specific surface antigen, soluble antigen or a toxin produced by the pathogen in the specimen. Sensitive antigenbased tests have been developed for malaria and Dengue ${ }^{21}$. Primary rapid protein-based and carbohydrate-based techniques include direct or latex agglutination using slides or cards and immunochromatography utilizing dipsticks or cassettes.

In latex agglutination tests, antibodies specific to the pathogen's antigens, such as bacterial polysaccharides, are covalently coupled to polystyrene particles and the complex is fixed onto a slide or card. On the addition of the specimen to the slide or card, if the specific carbohydrate or protein from the pathogen is present, the antigen cross-links the beads to give quantifiable agglutination. Alternatively, the pathogen's antigens, which can be polysaccharides, glycoproteins, glycolipids, proteoglycans or proteins, are covalently attached to the polystyrene particles to detect specific antibodies in the specimen ${ }^{38,42}$. Examples of agglutination-based tests for the detection of the antibody include the Leishmaniasis direct agglutination test $\mathrm{t}^{43}$ and the Leptospirosis microscopic agglutination test ${ }^{34}$. To minimize subjective interpretation of results, a pictorial-based approach to standardize results can be employed ${ }^{43}$.

In immunochromatographic assays, also known as lateral flow immunoassays, the principle is the same as in the enzymelinked immunosorbent assay sandwich method ${ }^{41}$. The immunological reaction takes place following capillary action on chromatographic paper, usually nitrocellulose membrane. Two kinds of specific antibody against the target protein, polysaccharide or glycoconjugate antigen, are used; one is dye-labelled and infiltrated into the sample pad attached at the end of the membrane or placed in a plastic well provided with the strip, while the other antibody is immobilized onto the chromatographic paper as the test line. At the control line, a secondary antibody, usually a human anti-IgG antibody or the target antigen is immobilized. If the target antigen is present in the specimen, the antigen forms a complex with the labelled antibody on the addition of the sample to the pad. The labelled antibody-antigen complex moves by capillary action until it reaches the capture molecule on the test line and forms a labelled antibody-antigen-immobilized antibody complex that generates a coloured line. Excess labelled antibody is in turn captured by the immobilized secondary antibody or antigen on the control line ${ }^{38}$. Alternatively, the double-antigen sandwich, in which one antigen is labelled and the other unlabelled, is used to detect specific antibodies in the specimen; at the test line, the labelled antigen-antibody complex interacts with the immobilized antigen to generate a coloured line. Any excess labelled antigen is captured by the immobilized antibody on the control line.

An immunochromatographic test for an IgG-mediated response against three mycobacterial antigens was able to distinguish between active pulmonary tuberculosis and other pulmonary diseases $^{8}$. The multiplex detection format used for the identification of more than one target species can be performed on the strip containing test lines equal to the number of target species to be analyzed ${ }^{44}$. For such tests, it is highly desirable to analyze multiple pathogens simultaneously under the same set of conditions. The multiplex detection format is very useful in clinical diagnosis where multiple pathogens that are interdependent in deciding the stage of diseases are to be detected. For instance, there is a virulent synergy between HIV and M. tuberculosis ${ }^{45}$ and simultaneous detection will inform on how to manage the patient better.

The benefits of rapid protein-based and/or carbohydratebased diagnostic tests include the flexibility to be tailor-made to detect antigen or antibody and the ease of performance requiring minimal training and limited or no instrumentation. Some tests, such as the rapid immunochromatographic IgG/ IgM test for diagnosis of active tuberculosis, are commercially available in a single-use, user-friendly format and require a very short time to produce visually interpreted results ${ }^{8}$. The test kits are relatively cheap to make, and are stable, allowing for long-term storage over a wide range of climates. The largely qualitative nature of the results of rapid protein-based and carbohydrate-based tests is, however, the major drawback. Besides, rapid tests such as the antigen-based rapid influenza diagnostic test can be less sensitive or less accurate compared to the traditional nucleic acid-based tests ${ }^{16,31}$.

Rapid nucleic acid-based diagnostic tests. Rapid nucleic acidbased tests have successfully been trialled for the diagnosis of respiratory ${ }^{16}$ and gastrointestinal ${ }^{36}$ pathogens. PCR is central to most nucleic acid-based tests. Rapid PCR-based tests have been effective for acute respiratory illnesses ${ }^{16,31}$. Firstly, the double-stranded target deoxyribonucleic acid (DNA) of the pathogen is denatured at a high temperature, followed by hybridisation of synthetic oligonucleotides to the complementary target gene. Lastly, polymerisation occurs when the primers, paired to the single-stranded DNA, are extended using deoxyribonucleotides in a reaction catalyzed by a thermostable polymerase. Cycles of the three steps result in the amplification of the specific target DNA such as the 16S rRNA (ribosomal ribonucleic acid) gene. The amplification products can be visualized as bands on an agarose gel by staining with ethidium bromide. Detection of these target regions is taken as evidence for the presence of the microorganism in the absence of the actual isolation of the pathogen. The downside, however, is that the nucleic acid sequence of the suspected pathogen must be known to design appropriate primers targeting conserved regions ${ }^{1}$. Besides, the detected DNA may be from non-viable pathogens from a controlled infection ${ }^{40}$.

In quantitative real-time PCR, as is being used for SARS-CoV- $2^{46}$, the fluorescent emission of a specific dye that attaches itself to the target amplicon allows the formation of the amplification products to be monitored continuously during the entire reaction ${ }^{47}$. Fluorescence intensity is directly proportional to the amount of amplified product, and the postamplification processing step (gel electrophoresis) is not necessary. Reverse-transcriptase PCR, as was employed in the 
detection of viral RNA in acute HIV- $1^{17}$ and influenza infection ${ }^{16}$, detects viable pathogens only. Multiplex PCR, as was used in the detection of gastrointestinal pathogens ${ }^{36}$, permits the simultaneous amplification of multiple gene products.

Nucleic acid-based techniques allow for the identification of morphologically indistinguishable pathogens or those pathogens hidden in host tissues ${ }^{36,47}$. The amplification of target sequences increases sensitivity ${ }^{36}$. Probes can be designed with the flexibility to permit the detection of a single species of a pathogen or a group of pathogens ${ }^{36}$.

While the production of durable portable PCR and electrophoresis devices has made it possible for the technology to be used in remote areas ${ }^{2}$, cost and complexity are still the major restrictions of nucleic-based diagnostic tests. The use of lyophilized reagents allows for long term stability in humid and hightemperature conditions and the simple procedures promote the ease of use by users in resource-limited settings ${ }^{10}$.

Some PCR-based devices use loop-mediated isothermal amplification to eliminate the need for a thermal cycler $^{47}$. In loop-mediated isothermal amplification, DNA is amplified at a constant temperature as the process uses a DNA polymerase that possesses strand displacement activity ${ }^{48-51}$. The denaturation step is not required as the single-stranded DNA serves as a template for DNA synthesis. Current assays have the additional advantage of having a multiplex detection feature incorporated $^{52}$. However, although loop-mediated isothermal amplification has been used for the detection of human influenza $\mathrm{A}^{50}$ and the $M$. tuberculosis complex ${ }^{51}$, it uses a complicated primer design ${ }^{48,49}$.

\section{Underlying science of other point-of-care diagnostics present on the market}

Advanced technology is being applied to develop multiplex point-of-care diagnostic tools that can detect the presence of several pathogens and allergens in a given specimen. Multiplex detection is particularly required in settings where co-infections are widespread and where emerging pathogens such as the Ebola and Zika viruses have extended their geographical zone. Multiple diseases presenting a similar set of symptoms can be tested with syndromic test panels ${ }^{21}$. Had they been implemented, broad pathogen detection assays could have identified the Ebola virus before its outbreak in West Africa ${ }^{2,11}$ and early detection would have removed a significant socioeconomic burden on affected communities ${ }^{11,12}$.

Multiplex diagnostic devices use array settings, hybridization papers, bead technology or microfluidic systems that can simultaneously detect multiple analytes ${ }^{10,53}$. The devices can detect proteins, nucleic acids, cells and metabolites in small quantities of the specimen, an advantage in resource-poor environments. Analysis of the test results, such as microarray-based detection is, however, based on programming that is built into the instrument ${ }^{53}$.

Microarray chips are collections of spots of nucleic acid, amino acid or sugar sequences attached on a solid surface, usually a microscope glass plate, nylon membrane or bead. Multiple copies of identical short synthetic, single-stranded nucleic acid sequences, capture proteins or glycans are arranged in rows and columns in a specific order ${ }^{54,55}$. The precise location and sequence of each spot are recorded in a computer database. The hybridisation technique or complementary binding is used to identify and quantify probe molecules, typically labelled with a fluorescent dye. If there is a reaction between the immobilized spot and the specific nucleic acid sequences, proteins or glycans representing the molecule of interest in the specimen, a fluorescent signal will occur that is read by a laser scanner ${ }^{53,54}$.

Microarrays have two major strengths. Firstly, microarrays require a very small amount of sample and so can be used for screening large numbers of specimens. Secondly, the technique can be customized to address specific needs.

Peptide microarrays can be used to identify key epitopes associated with an immune response to a specific or several pathogens, for inclusion in a single diagnostic test $\mathrm{t}^{25,56,57}$. Epitope discovery can likewise be used for the identification of therapeutic targets ${ }^{58}$ and vaccine development ${ }^{59,60}$. Furthermore, peptide arrays can be used in antigen-specific antibody profiling to monitor disease states and responses to therapy or vaccination $^{61,62}$. The weakness is that the correlation between protein activity and abundance is not always direct.

Carbohydrate microarrays enable the detection of pathogens through glycoconjugates on their cell surfaces, the identification of disease-related anti-glycan antibodies and the profiling of immune responses induced by vaccines or organ transplants ${ }^{55,63,64}$. As glycans attached to the solid surface are displayed in a multivalent manner, carbohydrate microarrays allow potential combinations to be analyzed. Assessment of the glycan-mediated binding events in turn enables the development of efficacious tools of diagnosis. Different subpopulations of serum antibodies that recognize the glycan structure can be distinguished using variations in glycan density ${ }^{55}$.

In nucleic acid microarray diagnosis, known oligonucleotides or complementary DNA to selected genes of pathogens are immobilized on a glass slide. Pathogen-specific oligonucleotides are used to amplify the nucleic acid in the specimen and the PCR products are labelled with a fluorescent or chemiluminescent dye and applied to the microarray. Under optimized conditions, only the nucleic acids derived from the pathogen will hybridize to the DNA on the glass slide ${ }^{53,54,65}$. Despite the expense of developing the microarray, acquiring the scanner and the software for data analysis, microarrays are still relatively cheaper than long-range sequencing.

Microfluidics is the science of designing, manufacturing and formulating devices/processes that deal with minute volumes of fluid. The technology is based on the transport of geometrically-constrained small volumes through channels in a glass or plastic chip ${ }^{66,67}$. When dimensions of a device or system become smaller, particles of fluid or particles suspended in the fluid become comparable in size with the apparatus itself, dramatically altering behavior such as capillary action of the 
system $^{67}$. Microfluidic devices have microchannels that are connected to the outside through inlet and outlet ports that allow precise and controlled experiments to be conducted in parallel. For every three-dimensional shape type, such as a rectangular chamber, as size decreases, the ratio of surface area to volume increases, making it favorable for microchannels to capture targets such as pathogens ${ }^{66,68}$. Besides, magnetic or electric fields are more effective at a short distance, making microfluidics ideal for sensing or detecting. Consequently, microfluidic systems are used to miniaturize or integrate conventional laboratory practices such as high-performance liquid chromatography, capillary electrophoresis, sandwich immunoassays and PCR by making lab-on-a-chip devices to save cost and reduce the time required for diagnosis ${ }^{67,68}$.

Application of next-generation sequencing has led to the development of genomic-based systems for diagnosis in which sequencing can be done directly from a sample without the need to culture ${ }^{2,47}$. While this technology has largely been limited to well-resourced settings, development of pocket-sized devices that can be plugged into the USB of a laptop, such as MinION manufactured by Oxford Nanopore Technologies, has made it conceivable to deploy the sequencer to endemic regions such as Ebola-infected tropical areas ${ }^{2,69,70}$.

Nanopore sequencing uses electrophoresis to transport an unknown sample of nucleic acid through a nanopore, an opening of generally a few nanometres in diameter, usually in a biological membrane. During translocation, each nucleotide blocks the nanopore differently, giving a different amplitude and duration of the blockade and this information is converted into nucleic acid sequence information ${ }^{71,72}$. A nanopore-based diagnostic tool detects target molecules at a very low concentration and screens a panel of biomarkers or genes without the need for PCR amplification or chemical labelling of the sample. This provides fast analysis leading to the rapid identification of the pathogen. Besides, the device enables the detection of polymicrobial infections, monitoring virulence, anti-microbial resistance genes and clusters of transmission ${ }^{1,2}$. The presence of clusters of transmission in patients with HIV-1 has been detected through sequencing and viral variants linked through phylogenetic studies ${ }^{73}$.

The bottleneck of using a genomic-based system for diagnosis, particularly in rural Africa, is access to the internet for dissemination of data $^{2}$. It is also possible to mistake a target for its close relative, as identification of the pathogen is dependent on the reference database ${ }^{2,69}$. Furthermore, during sequencing, the high speed of translocation of the molecule makes it difficult to reliably distinguish amongst the different nucleotides, leading to a high error rate and low sensitivity. Subsequently, the method is unsuitable for single nucleotide polymorphism sequencing ${ }^{69}$.

The requirement for highly specialized equipment for multiplex diagnosis has been the constraint in resource-limited settings such as rural Africa. Nonetheless, even though high-tech methods are currently expensive to operate, as the technology develops, costs also decrease ${ }^{2,47}$. It is feasible that in the future these methods will be available for routine use in resource-limited settings ${ }^{74}$.

\section{Antibody serological detection as a diagnostic tool}

For most communicable diseases, infection leads to changes in the antibody repertoire of the patient and detection of antibodies against the pathogen is a very effective way of distinguishing between past and current infections $\mathrm{s}^{8,75}$. However, for some acute infections, including the water-borne bacterial diseases such as cholera, typhoid, dysentery and other diarrheal diseases, the serological signature occurs over days, meaning that immediate diagnosis post-infection when it is critical to take prophylactic action ${ }^{20,36}$ is not possible. If immunodiagnostic tests are to be used to detect such infections, key antibodies that detect antigens of the pathogen in the specimen need to appear before pathology overwhelms the patient ${ }^{20,37,58}$.

In some infections, such as hepatitis, antibodies may not reach detectable levels until months after the acute infection. A certain proportion of infected patients never demonstrate an increase in specific antibody levels, necessitating the use of other diagnostic tests ${ }^{8}$. Often there is a spectrum of responses in infected individuals ${ }^{76,77}$ with some developing antibodies from sub-clinical infection or after colonization by the pathogen without actually having symptoms of the disease. Factors that influence the immune response include age, sex, genetic make-up, vaccination history and the prevalence and intensity of infection. Therefore, an increase in antibody levels must be carefully correlated with the symptoms of the specific disease or suspected pathogen ${ }^{20,77}$.

\section{Systems biology approaches informing diagnosis}

In recent years, scientists have taken a holistic approach in which they not only detect the presence of a pathogen but determine the circumstances that could promote infection and treatment. Apart from polymorphisms, the strength of one's immune system plays a critical role in how one responds to infection, particularly if antibody-based diagnostic tests are used. Specifically, acquired immunity improves with repeated exposure to the pathogen. While maternal exposure and breastfeeding will determine how the infant manages in the first few months of life ${ }^{29,78}$, immune function is developed in early childhood, continuing into adult life ${ }^{79}$. The development of the immune system is mainly influenced by the genetic make-up of the individual and the intensity and range of pathogens present in the environment. In patients with an already weakened immune system, the antibody response is slow, making it difficult to specify the cause of the disease. Co-infections also affect how the immune system responds to subsequent infections ${ }^{26,28}$.

During disease, networks are perturbed from their normal states $^{29,76}$. For instance, when the body fights bacterial infection, sepsis may develop when chemicals of the immune system are released into the bloodstream ${ }^{40,80}$. Informative diagnostic biomarkers of diseases can be identified through analyzing biological systems. This Systems Biology approach views biology as information science and studies biological systems as a whole 
and their interactions with the environment ${ }^{76}$. Integrating information at different levels to understand the interactions between the biological system and its environment will help untangle how biological systems respond. Subsequently, underlying causes of disease can be identified, treatment strategies designed and preventative measures developed ${ }^{29,76}$.

Essential networks in disease diagnosis include host-microbiome and immune-metabolic interactions. The human microbiome is the full complement of microorganisms, their genes and genomes in a particular environment, and shares body space such as the gut or the skin. The interaction between the host and its microorganisms is symbiotic as long as the normal balance of microorganisms is not disturbed. Surveys have revealed that when the balance of the microbial community is disrupted, fungal species like Candida can flourish and cause disease ${ }^{81}$. Differences in gut bacterial diversity, taxa composition and metabolism have been reported between HIV-infected and HIV-uninfected individuals ${ }^{82}$. Changes in the gut microbiome and microbial metabolism profiles have been linked to mucosal and systemic inflammation, microbial translocation and markers of disease ${ }^{82,83}$.

The colonization of the gut and the skin begins immediately after birth, being populated through maternal vaginal flora and breastfeeding; making birth route and diet the initial critical factors. Homeostatic regulatory pathways involve interactions between immune cells and metabolic products and impact the set point for an immune response ${ }^{29}$. The level of sanitation and exposure to antibiotics also influence the development of the infant's microbiome ${ }^{79}$. The rate of expansion of bacterial diversity slows down after three years of age ${ }^{84,85}$. The microbiome helps establish immune tolerance and stimulates the host-mucosa associated immune system to respond quickly to invasion by pathogens, and may inhibit colonisation by pathogens through antagonism ${ }^{84,86}$. For instance, the gut microbiome may prevent disease-causing bacteria from sticking to and penetrating the intestinal wall ${ }^{87}$.

Alterations in the gut microbiome, which in turn regulates the host immune-metabolic interaction, have been linked to the nutritional status of an individual. Metabolites produced by the microbiome or nutritional constituents such as vitamin D and indole-3-carbinol, modulate the immune system. These molecules activate local haematopoietic cells and maintain the integrity of the gut mucosal barrier, while omega-3 polyunsaturated fatty acids interact with adipose tissue immune cells. There must be a balance between the conservation of energy by metabolic systems and the draining of energy by immune-defence mechanisms ${ }^{29,79}$. The body, its microbiome and pathogens all compete for the available nutrients or metabolites. For example, an increase in available iron allows pathogens such as $P$. falciparum, HIV-1 and M. tuberculosis to thrive, leading to a change in the gut microbiome. The presence of infectious agents leads to an increase in the peptide hormone hepcidin which blocks the absorption of dietary iron leading to anaemia ${ }^{88-90}$.
Unavailability of iron, in turn, impairs the production of macrophages, $\mathrm{B}$ and $\mathrm{T}$ cells of the immune system. Immunemetabolic interactions are therefore influenced directly, by the nutritional status of the host or indirectly by the altered microbiome. These factors need to be considered in the diagnosis and treatment of both metabolic and infectious diseases ${ }^{29,79,88,91}$.

A better-developed microbiome can be promoted through exposure to a diverse range of microorganisms in the environment, breastfeeding ${ }^{78,85}$ and the intake of probiotics ${ }^{92}$ such as yoghurt. On the contrary, stress, drugs such as inappropriate use of antibiotics $^{93}$ and certain diets ${ }^{94}$ may predispose individuals to a variety of diseases. The stability of the microbiome has also been observed to be age-dependent, with elderly individuals having a less stable microbiome ${ }^{79}$.

In addition to considering the effects of host-microbiome interactions, expression proteomics is increasingly being used in the diagnosis of disease ${ }^{29}$. Expression proteomics is the qualitative and quantitative study of proteins expressed in samples that differ by a certain variable. A cell responds to internal and external changes by regulating the activity and level of its proteins ${ }^{89,90}$. Strong gene expression, resulting in abundant mRNA, does not necessarily mean that the corresponding protein is also abundant or indeed active in the cell ${ }^{54}$. The presence of a pathogen can trigger different patterns of gene expression and protein modification ${ }^{29,90}$. Proteins differentially expressed in diseased and healthy tissues help in the identification of serum biomarkers; a protein only found in a diseased sample may represent a useful diagnostic marker.

To be useful in the diagnosis of acute infections, biomarkers must be both expressed and identified at the onset of infection. A case in point is the early production of pro-inflammatory and immunosuppressive cytokines, the complement system protein $\mathrm{C} 4$ and natural killer cells in the development of severe sepsis or sepsis shock ${ }^{80}$. Yet, the gold standard blood culture sepsis diagnostic test is too slow to significantly influence the initial management of patients ${ }^{40}$. Diagnostic methods that detect the early markers would be more effective in the management of sepsis.

\section{Detection of SARS-CoV-2, causative agent of the emerging viral disease COVID-19}

The current COVID-19 pandemic reiterates the need for better preparedness to detect and control acute infections. COVID-19 is caused by the virus SARS-CoV-2 ${ }^{46,95}$. SARS-CoV-2 is a single-stranded, positive-sense RNA virus and its entire genetic sequence was uploaded to the Global Initiative on Sharing All Influenza Data (GISAID) platform on the $10^{\text {th }}$ of January $2020^{46,96}$. Accurate and efficient testing during the early stages of the infection avoids unnecessary quarantines of negative individuals and the spread of infection by positive individuals ${ }^{77}$. Currently, tests are largely carried out on suspected cases and the decision to test is based on clinical and epidemiological factors that suggest the likelihood of infection in the individual. 
The mean incubation period for SARS-CoV-2 is about 5 days but varies widely amongst individuals ${ }^{95}$. Further investigations are required to better understand the virus shedding patterns to inform optimal specimen collection. Respiratory samples have the highest yield but the virus has also been detected in other specimens such as stool and blood ${ }^{46,95}$.

Both nucleic acid-based and immunoassay-based types of diagnostics are available for detecting SARS-CoV-2. Nucleic acid-based methods detect the SARS-CoV-2 viral RNA in infected individuals. On the other hand, immunoassay methods detect antibodies produced by individuals after exposure to the virus or detect antigenic proteins in infected individuals. Individuals who develop antibodies to the virus could be potential convalescent plasma donors and provide an opportunity to monitor the immune status over time ${ }^{46}$. Assessment can then be made to determine if the presence of antibodies against SARS-CoV-2 correlates with immunity to the virus.

Detection of unique sequences of the viral RNA using PCRbased methods such as real-time reverse-transcriptase PCR (rRT-PCR) is used for routine confirmation of cases ${ }^{46,95}$. If necessary, the results are ratified by nucleic acid sequencing. The viral sequences targeted include the nucleocapsid $(\mathrm{N})$, envelope (E), spike (S) and the RNA-dependent RNA polymerase (RdRP) genes. At present, no other SARS-like coronaviruses are circulating in the human population and positive tests are identified in two ways. Firstly, positive PCR-based detection of at least two different targets on the SARS-CoV-2 virus genome, of which one target is preferably specific. Secondly, one positive PCR-based detection of a betacoronavirus target and SARS-CoV-2 further identified by sequencing of a larger or different target from the probed amplicon ${ }^{95,96}$.

Serological tests are currently under development and validation as the dynamics of the immunological response, the severity of the disease in various populations and the relationship between the viral concentration and the severity of the disease are still to be understood $77,95,97$. Furthermore, cross-reactivity with other coronaviruses is a challenge as this would give false-positive results ${ }^{46,96}$. In surviving patients, paired serum, acute and convalescent can be useful to define cases retrospectively once validated tests are available. The attack rate and extent of an outbreak could also be assessed retrospectively ${ }^{95}$.

In some patients, seroconversion for $\operatorname{IgG}$ and $\operatorname{IgM}$ occurred within three weeks after symptom onset ${ }^{77,97}$. The antibodies were specific for viral antigens that include the spike glycoprotein and the nucleocapsid protein. Some patients may be seropositive and yet test negative with nucleic-based assays due to clearance of an earlier milder infection. Virus-specific antibody detection can, therefore, complement PCR-based methods for diagnosis of suspected cases with negative rRT-PCR results, and in the identification of asymptomatic infections in close contacts $^{46,77,96,97}$.

Antigen-based tests can confirm the infection status, but cases can be missed early in infection when viral load is low, or due to changes in viral load over the course of the infection or sampling variability ${ }^{96,98}$. To identify a suitable diagnostic target, knowledge of the proteins expressed during the course of infection, abundance and ease of detection is required ${ }^{12}$. High avidity and highly specific monoclonal antibodies ${ }^{12}$ that detect pathogen-derived antigens, however, need to be developed if antigen-based detection assays are to be used effectively ${ }^{98}$.

Different parameters of nucleic acid-based and immunoassay types of diagnostics are summarized in Table $3^{46,77,95,96,98}$.

Given that the SARS-CoV-2 pathogen is highly infectious, virus isolation is not recommended for routine testing ${ }^{98}$. Regular sequencing of the virus from a percentage of specimens from clinical cases will, however, help to monitor the rate and variability of the viral genome mutations that may affect diagnostic tests and inform the development of effective vaccines $^{46,95}$.

While there has been rapid progress in the development of diagnostic kits for SARS-CoV-2 in the last few months, more efficient laboratory techniques and cost-effective point-of-care kits that can be deployed in mass quantities are required. Such tests will speed up the response time for treatment and eliminate the need for specialized laboratory equipment and waiting time involved with testing in approved laboratories ${ }^{46,98}$.

\section{Implementation of diagnosis and control of acute infections in poor resource settings in Africa}

To reduce incidences and control outbreaks of diseases, there is an increasing interest in early detection, on-going monitoring and real-time results of infectious diseases ${ }^{11,19,32,39,74}$. Consequently, it is necessary to improve national surveillance and diagnostic capacity ${ }^{11,20,24}$. The ability to quickly identify biomarkers linked to disease or environmental conditions ${ }^{20,23}$ allows for more effective prediction, diagnosis or monitoring of disease. Subsequently, effective treatments can be prescribed immediately ${ }^{8,24,36}$, public health reporting can be enhanced ${ }^{74}$ and preventative measures can be put in place to facilitate outbreak containment ${ }^{10,11,17}$.

The existence of co-infections and emerging pathogens that have extended their geographical region has highlighted the lack of healthy controls and reference standard tests ${ }^{19,21,23,24}$. This has led to the realization that present state-of-the-art diagnostic approaches which often use a pathogen by pathogen style ${ }^{11,12}$ are inadequate in controlling acute infections. While new rapid diagnostic tests for tropical diseases ${ }^{18}$ and multiplexed biomarker assays have been developed ${ }^{99,100}$, they have not been validated or made commercially available in low-resource settings $^{11,18,23}$. Co-infections and low nutritional status could undermine the effectiveness of these host biomarker assays ${ }^{23}$, making validation before implementation in these settings imperative ${ }^{12}$.

Generally, protein- and/or carbohydrate-based tests are appropriate for the diagnosis of co-infections whereas nucleic acid-based tests would be required for emerging pathogens. 


\section{Table 3. Comparison of nucleic acid-based methods and immunodiagnostic assays in the diagnosis of severe acute respiratory syndrome coronavirus 2 (SARS-CoV-2).}

\begin{tabular}{|c|c|c|c|}
\hline \multirow[t]{2}{*}{ Parameter } & \multicolumn{3}{|l|}{ Diagnostic Method } \\
\hline & Nucleic acid-based & Antibody-based & Antigen-based \\
\hline Basis of diagnosis & $\begin{array}{l}\text { Detects presence of viral genetic } \\
\text { material in the specimen }\end{array}$ & $\begin{array}{l}\text { Detects presence of anti-viral } \\
\text { antibodies in the specimen }\end{array}$ & $\begin{array}{l}\text { Detects presence of viral } \\
\text { proteins in the specimen }\end{array}$ \\
\hline Place of testing & $\begin{array}{l}\text { Centralized facilities due to high } \\
\text { technical expertise and equipment } \\
\text { requirements }\end{array}$ & $\begin{array}{l}\text { May be in or outside a central } \\
\text { laboratory depending on test } \\
\text { design }\end{array}$ & $\begin{array}{l}\text { May be in or outside a central } \\
\text { laboratory depending on test } \\
\text { design }\end{array}$ \\
\hline $\begin{array}{l}\text { Type of specimen } \\
\text { and risk of handling }\end{array}$ & $\begin{array}{l}\text { Respiratory samples; high risk of } \\
\text { infection }\end{array}$ & Blood samples; low risk of infection & $\begin{array}{l}\text { Blood samples; low risk of } \\
\text { infection }\end{array}$ \\
\hline Point of diagnosis & At or before onset of symptoms & $\begin{array}{l}\text { At least few days from onset of } \\
\text { symptoms }\end{array}$ & At onset of symptoms \\
\hline Positive result & $\begin{array}{l}\text { Confirms current infection and ensures } \\
\text { timely treatment }\end{array}$ & Indicates recent or past infection & $\begin{array}{l}\text { Confirms current infection and } \\
\text { ensures timely treatment }\end{array}$ \\
\hline Use & Testing probable cases & $\begin{array}{l}\text { Assessing asymptomatic individuals } \\
\text { and extent of outbreak }\end{array}$ & Testing probable cases \\
\hline Limitations & $\begin{array}{l}\text { Affected by sampling factors } \\
\text { Cannot identify prior infection in } \\
\text { asymptomatic patients post recovery }\end{array}$ & $\begin{array}{l}\text { Detects immune response; cannot } \\
\text { confirm infection status }\end{array}$ & $\begin{array}{l}\text { Requires monoclonal antibodies } \\
\text { so takes longer to develop }\end{array}$ \\
\hline
\end{tabular}

Instead of using multiple kits for diagnosis of different infections, we propose that multiplexing be custom-made from a panel of antigens for specific countries depending on the profile of prevalent endemic infections. The adaptation of diagnosis and surveillance capacity to specific country needs has also been suggested by Kelly-Cirino and co-workers ${ }^{11}$. For instance, in Zimbabwe, a diagnostic tool that can simultaneously detect diarrheal or water-borne diseases such as cholera, dysentery and typhoid, in addition to HIV and TB or malaria is essential, particularly for children. In East Africa, where there is a close association between people and livestock or wildlife ${ }^{19}$, it is of utmost importance to include the detection of bacterial zoonoses such as brucellosis in addition to the endemic diseases such as visceral leishmania. As a starting point, the tool could use antigen-based detection for acute infections and the already in-use antibody detection for the endemic infectious agents. Inclusion of several specific antibodies isolated from convalescent or asymptomatic individuals in antigen-based diagnosis would increase both sensitivity and accuracy of detection.

Normally, medical resources are limited in rural and low-income urban areas of Africa and the lower the cost of the diagnostic test the more eagerly it will be used. Generally, the cost per rapid diagnostic test is more than traditional methods of testing. However, affordability should not only consider the cost of the diagnostic test, but also the benefit of reaching the correct diagnosis. This assessment of affordability should include averted treatment costs and losses due to illness or death, as well as reduced pain and suffering to patients ${ }^{2,30}$. The effectiveness of the diagnostic test in comparison to other available tests will be determined by the health outcome and show whether or not health care funds have been put to good use ${ }^{32}$. In rural Africa, this would be true where, for example, the loss of lives due to cholera outbreaks would be minimized. Affordability constraints can be minimized by working to reduce the cost per test and hands-on time by the health practitioner, carefully designing algorithms ${ }^{19}$ to use the tests cost-effectively and educating users on the interpretation of results ${ }^{18}$ and the cost-savings from more efficient use of therapeutic drugs.

Acute infections require immediate intervention thus diagnostic tests need to be quick and accurate to inform treatment and control strategies ${ }^{8,11,30}$. The diagnosis must be performed on-site with minimum expertise and processing of results, yet accuracy must wherever possible, match reference level laboratory tests. In some countries like Zimbabwe, diagnosis and confirmation of notifiable diseases have been reserved for a few laboratories used as sentinel sites $^{9}$ but the urgency of dealing with acute infections, such as COVID-19, necessitates the focus on decentralized testing ${ }^{10,32,36}$. Rapid diagnosis is apt for initial or crisis screening where sample preparation is simple, enabling many samples to be processed within a short time. However, as rapid diagnostic tests can be less sensitive or less accurate compared to existing tests ${ }^{20}$, this presents a challenge requiring the on-site laboratory to work hand-in-hand with the central laboratory for comparison of results ${ }^{32}$. Ideally, a screen test ought to be very sensitive as having to carry out a confirmatory test is not cost-effective and not useful as patients may have been lost at the first screen. 
The availability of rapid diagnostic tests allows tests to be performed in remote areas at the periphery of health systems, where electricity and the internet may not be available, without the need to transport the specimen to a microbiology laboratory for analysis ${ }^{30}$. Such tests need to be portable for ease of distribution. In many developing countries the procurement and distribution systems are poorly developed ${ }^{101}$. Ideally, there should be a central purchasing and supply system with inventory control for bulk purchasing. This synchronization centre or satellite centres, where distances involved would increase transport costs, would be responsible for storing supplies per manufacturer's recommended storage conditions and ensuring that stocks are used appropriately ${ }^{32}$. Extreme weather conditions, humid and hot, demand that the kits be stable, preferably having a shelf life of more than a year without refrigeration. Unless lyophilized reagents are used, most tests, unfortunately, have limited shelf life, and this increases the demands on procurement and distribution. Local government regulations, quality assurance, shelf-life testing and distribution systems all need to be assessed and improved.

Rapid diagnostic kits need to be designed by experts along the lines of those already accepted in the market ${ }^{11}$, requiring minimal education by both the users and regulators ${ }^{32}$. The diagnostic test must be acceptable to policymakers who dictate that the test should have sufficient sensitivity and specificity for approval by international health and donor agencies. Clinicians require adequate predictive values and ease of $\mathrm{use}^{32,102}$. The test must be perceived as credible by the patients; if the test is perceived to be too simple, the patients may not trust the results. The specimens to be used must be culturally appropriate and acceptable for both the clinician and the patient. In rural settings, particularly where children are involved, non-invasive methods of obtaining the sample are preferred, making the use of urine desirable over serum as a specimen ${ }^{75,102}$. In the long run, an effective diagnostic device has standardized performance, is scientifically validated across different populations and in practice, is accepted by different people across different cultures. To this end, the newly established World Health Organisation Diagnostic Technical Advisory Group has been set up to ensure that any new test developer abides by the criteria that is accepted by the field. Review by external consultation before endorsement is a critical process in addressing attributes of sensitivity and specificity of a test ${ }^{103}$.

The final decision on whether or not a medical test can be performed lies with the regulators and often the regulatory pathways are not clear $^{2,23,101}$. The decision must be made following country-level technical assessments and evaluation by referral laboratories of factors such as cost, current and continued availability, shelf-life and storage requirements. As a requisite, the central public health laboratory also evaluates the tests using local specimens to confirm sensitivity and specificity in their particular setting. The central laboratory must then develop and periodically update algorithms to reduce the time of diagnosis $s^{10,17,95}$, write standard operating procedures and run training courses for peripheral laboratories. Algorithms, decision trees or visual schemes, should include behavioural, biological or genetic risk factors for the disease, clinical signs and symptoms and use of other tests. Often the true burden of other febrile diseases has been understated as clinical algorithms have been designed for specific disease management such as malaria ${ }^{18,21}$. Disease incidence and prevalence ${ }^{20,23}$, availability and accuracy of other tests and the probable consequences of misdiagnosis ${ }^{1,18}$ of the disease should also be included.

For the adoption of the test, the referral laboratories should then advise national governments, which in turn should take responsibility for implementation ${ }^{14,18}$. Responsibility for disease control should not be delegated, deliberately or by neglect to commercial enterprises, donor agencies or external aid programmes. After all, national governments are the ones under scrutiny from the media, rumours and political pressure; for these regulators time is critical. Swift and accurate results will enable the regulators to both contain the disease outbreak and to manage information.

\section{Conclusions}

Acute infections require that the method of diagnosis be primarily rapid but accurate for appropriate treatment and containment to be administered. Diagnostic tools must be developed based on the profile of prevalent endemic infections and those of surrounding regions. In rural and low-income urban areas of Africa, ease of use, affordability, availability and acceptability by patients, clinicians and most importantly by regulators, will determine how widely a rapid point-of-care diagnostic tool will be used. For effective control of acute infections, in addition to biological variabilities such as polymorphisms, the possibility of co-infections, emerging infections, the nutritional status and the patient's microbiome need to be taken into consideration when assessing the spectrum of responses in infected individuals.

\section{Data availability}

No data are associated with this article.

\section{Acknowledgements}

We are grateful to the National Institute for Health Research (NIHR) Global Health Research Programme (16/136/33) for funding the post-doctoral fellowship during which time the article was drafted. The views expressed in this publication are those of the authors and not necessarily those of the NIHR or the Department of Health and Social Care. We also thank all the members of the Parasite Immuno-epidemiology Group at the University of Edinburgh whose valuable comments helped to shape the manuscript. 
1. Koehler JW, Douglas CE, Minogue TD: A highly multiplexed broad pathogen detection assay for infectious disease diagnostics. PLOS Negl Trop Dis. 2018; 12(11): e0006889.

PubMed Abstract | Publisher Full Text | Free Full Text

2. Gardy JL, Loman NJ: Towards a genomics-informed, real-time, global pathogen surveillance system. Nat Rev Genet 2018; 19(1): 9-20. PubMed Abstract | Publisher Full Text | Free Full Text

3. Snow RW, Guerra CA, Noor AM, et al.: The global distribution of clinical episodes of Plasmodium falciparum malaria. Nature. 2005; 434(7030): 214-7. PubMed Abstract | Publisher Full Text | Free Full Text

4. Nkumama IN, O'Meara WP, Osier FHA: Changes in malaria epidemiology in Africa and new challenges for elimination. Trends Parasitol. 2017; 33(2): $128-40$.

PubMed Abstract | Publisher Full Text | Free Full Text

5. Fenwick A: Waterborne infectious diseases--could they be consigned to history? Science. 2006; 313(5790): 1077-81. PubMed Abstract | Publisher Full Text

6. Mpenyana-Monyatsi L, Onyango MS, Momba MNB: Groundwater quality in a South African rural community: A possible threat to public health. Pol Environ Stud. 2012; 21(5): 1349-58. Reference Source

7. Su W, Gao X, Jiang L, et al.: Microfluidic platform towards point-of-care diagnostics in infectious diseases. J Chromatogr A. 2015; 1377: 13-26. PubMed Abstract | Publisher Full Text

8. Ben-Selma W, Harizi $\mathrm{H}$, Boukadida J: Immunochromatographic IgG/IgM test for rapid diagnosis of active tuberculosis. Clin Vaccine Immunol. 2011; 18(12): 2090-4.

PubMed Abstract | Publisher Full Text | Free Full Text

9. Mashe T, Gudza-Mugabe M, Tarupiwa A, et al.: Laboratory characterisation of Salmonella enterica serotype Typhi isolates from Zimbabwe, 2009-2017. BMC Infect Dis. 2019; 19(1): 487.

PubMed Abstract | Publisher Full Text | Free Full Text

10. Alp A: Advancement in POCT molecular testing: the multiplex PCR POCT devices for infectious diseases. EJIFCC. 2018; 29(3): 205-209. PubMed Abstract | Free Full Text

11. Kelly-Cirino $\mathrm{CD}$, Nkengasong J, Kettler $\mathrm{H}$, et al.: Importance of diagnostics in epidemic and pandemic preparedness. BMJ Glob Health. 2019; 4(Suppl 2): e001179.

PubMed Abstract | Publisher Full Text | Free Full Text

12. Peeling RW, Murtagh M, Olliaro PL: Epidemic preparedness: why is there a need to accelerate the development of diagnostics? Lancet Infect Dis. 2019; 19(5): e172-e8.

PubMed Abstract | Publisher Full Text

13. WHO: Health Emergency Information and Risk Assessment. World Health Organisation; 2020; [Weekly Bulletin on Outbreaks and Other Emergencies] Reference Source

14. Fonkwo PN: Pricing Infectious Disease. The economic and health implications of infectious diseases. EMBO Rep. 2008; 9 Suppl 1(Suppl 1): S13-S7.

PubMed Abstract | Publisher Full Text | Free Full Text

15. Smith KM, Machalaba CC, Seifman R, et al.: Infectious disease and economics: The case for considering multi-sectoral impacts. One Health. 2019; 7: 100080. PubMed Abstract | Publisher Full Text | Free Full Text

16. Chu HY, Englund JA, Huang D, et al.: Impact of rapid influenza PCR testing on hospitalization and antiviral use: a retrospective cohort study. J Med Virol. 2015: 87(12): 2021-6.

PubMed Abstract | Publisher Full Text | Free Full Text

17. Cohen MS, Shaw GM, McMichael AJ, et al.: Acute HIV-1 infection. $N$ Engl J Med. 2011; 364(20): 1943-54.

PubMed Abstract | Publisher Full Text | Free Full Text

18. Stoler J, Awandare GA: Febrile illness diagnostics and the malaria-industria complex: a socio-environmental perspective. BMC Infect Dis. 2016; 16(1): 683. PubMed Abstract | Publisher Full Text | Free Full Text

19. Maze MJ, Bassat Q, Feasey NA, et al.: The epidemiology of febrile illness in sub-Saharan Africa: implications for diagnosis and management. Clin Microbiol Infect. 2018; 24(8): 808-14.

PubMed Abstract | Publisher Full Text | Free Full Text

20. Bhaskaran D, Chadha SS, Sarin S, et al.: Diagnostic tools used in the evaluation of acute febrile illness in South India: a scoping review. BMC Infect Dis. 2019; 19(1): 970.

PubMed Abstract | Publisher Full Text | Free Full Text

21. Chappuis F, Alirol E, d'Acremont V, et al.: Rapid diagnostic tests for nonmalarial febrile illness in the tropics. Clin Microbiol Infect. 2013; 19(5): 422-31. PubMed Abstract | Publisher Full Text

22. Schroeder LF, Amukele T: Medical laboratories in sub-Saharan Africa that meet international quality standards. Am J Clin Pathol. 2014; 141(6): 791-5. PubMed Abstract | Publisher Full Text

23. Escadafal C, Nsanzabana C, Archer J, et al.: New biomarkers and diagnostic tools for the management of fever in low- and middle-income countries: An overview of the challenges. Diagnostics (Basel). 2017; 7(3): 44. PubMed Abstract | Publisher Full Text | Free Full Text

24. Guillebaud J, Bernardson B, Randriambolamanantsoa TH, et al.: Study on causes of fever in primary healthcare center uncovers pathogens of public health concern in Madagascar. PLoS Negl Trop Dis. 2018; 12(7): e0006642. PubMed Abstract | Publisher Full Text | Free Full Text

25. Sabalza M, Barber CA, Abrams WR, et al.: Zika virus specific diagnostic epitope discovery.J Vis Exp. 2017; (130): e56784.

PubMed Abstract | Publisher Full Text | Free Full Text

26. Chang CC, Crane M, Zhou J, et al.: HIV and co-infections. Immunol Rev. 2013; 254(1): 114-42

PubMed Abstract | Publisher Full Text | Free Full Text

27. Osakunor DNM, Sengeh DM, Mutapi F: Coinfections and comorbidities in African health systems: At the interface of infectious and noninfectious diseases. PLoS Negl Trop Dis. 2018; 12(9): e0006711. PubMed Abstract | Publisher Full Text | Free Full Text

28. Thumbi SM, de Clare Bronsvoort BM, Poole EJ, et al.: Parasite co-infections and their impact on survival of indigenous cattle. PLOS One. 2014; 9(2): 76324.

PubMed Abstract | Publisher Full Text | Free Full Text

29. Smith $\mathrm{CL}$, Dickinson $\mathrm{P}$, Forster $\mathrm{T}$, et al.: Identification of a human neonatal immune-metabolic network associated with bacterial infection. Nat Commun. 2014; 5: 4649 .

PubMed Abstract | Publisher Full Text | Free Full Text

30. Spaeth BA, Shephard M, Omond R: Clinical application of point-of-care testing in the remote primary health care setting. Qual Prim Care. 2017 25(3): 164-75. Reference Source

31. Rogan DT, Kochar MS, Yang S, et al.: Impact of rapid molecular respiratory virus testing on real-time decision making in a pediatric emergency department. J Mol Diagn. 2017; 19(3): 460-7. PubMed Abstract | Publisher Full Text | Free Full Text

32. Patel K, Suh-Lailam BB: Implementation of point-of-care testing in a pediatric healthcare setting. Crit Rev Clin Lab Sci. 2019; 56(4): 239-246. PubMed Abstract | Publisher Full Text

33. Zhu C, Sidiki S, Grider B, et al.: A Study of the Use and Outcomes From Respiratory Viral Testing at a Mid-Sized Children's Hospital. Clin Pediat (Phila). 2019; 58(2): 185-90.

PubMed Abstract | Publisher Full Text | Free Full Text

34. Larsson A, Greig-Pylypczuk R, Huisman A: The state of point-of-care testing: a European perspective. Ups J Med Sci. 2015; 120(1): 1-10.

PubMed Abstract | Publisher Full Text | Free Full Text

35. Dunay S, Bass J, Stremick J: Leptospirosis: a Global Health Burden in Review. Emerg Med. 2016; 6: 5 Publisher Full Text

36. Keske S, Zabun B, Aksoy K, et al.: Rapid molecular detection of gastrointestinal pathogens and its role in antimicrobial stewardship. J Clin Microbiol. 2018; 56(5): e00148-18.

PubMed Abstract | Publisher Full Text | Free Full Text

37. Dorny $P$, Brandt J, Zoli A, et al: Immunodiagnostic tools for human and porcine cysticercosis. Acta Trop. 2003; 87(1): 79-86.

PubMed Abstract | Publisher Full Text

38. Yang Y, Cai YN, Tong MW, et al.: Serological tools for detection of Trichinella infection in animals and humans. One Health. 2016; 2: 25-30. PubMed Abstract | Publisher Full Text | Free Full Text

39. Xie SY, Yuan M, Ji MJ, et al.: Immune responses result in misdiagnosis of Schistosoma japonicum by immunodiagnosis kits in egg-positive patients living in a low schistosomiasis transmission area of China. Parasit Vectors. 2014; 7(1): 95 PubMed Abstract | Publisher Full Text

40. Sinha $M$, Jupe J, Mack $H$, et al.: Emerging Technologies for Molecular Diagnosis of Sepsis. Clin Microbiol Rev. 2018; 31(2): e00089-17. PubMed Abstract | Publisher Full Text | Free Full Text

41. Koivunen ME, Krogsrud RL: Principles of immunochemical techniques used in clinical laboratories. Lab Med. 2006; 37(8): 490-7. Publisher Full Text

42. Molina-Bolívar JA, Galisteo-González F: Latex immunoagglutination assays. Journal of Macromolecular Science, Part C: Polymer Reviews. 2005; 45(1): 59-98. Publisher Full Text

43. Adams $E R$, Jacquet $D$, Schoone $G$, et al.: Leishmaniasis direct agglutination test: using pictorials as training materials to reduce inter-reader variability and improve accuracy. PLoS Negl Trop Dis. 2012; 6(12): e1946. PubMed Abstract | Publisher Full Text | Free Full Text

44. Kim H, Chung DR, Kang M: A new point-of-care test for the diagnosis of infectious diseases based on multiplex lateral flow immunoassays. Analyst. 2019; 144(8): 2460-6. PubMed Abstract | Publisher Full Tex 
45. Parsons LM, Somoskövi Á, Gutierrez C, et al:: Laboratory diagnosis of tuberculosis in resource-poor countries: challenges and opportunities. Clin Microbiol Rev. 2011; 24(2): 314-50. PubMed Abstract | Free Full Text

46. Carter LJ, Garner LV, Smoot JW, et al.: Assay techniques and test development for COVID-19 diagnosis. ACS Cent Sci. 2020; 6(5): 591-605. PubMed Abstract | Publisher Full Text | Free Full Text

47. Fournier PE, Dubourg G, Raoult D: Clinical detection and characterization of bacterial pathogens in the genomics era. Genome Med. 2014; 6(11): 114. PubMed Abstract | Publisher Full Text | Free Full Text

48. Fu S, Qu G, Guo S, et al.: Applications of loop-mediated isothermal DNA amplification. Appl Biochem Biotechnol. 2011; 163(7): 845-50. PubMed Abstract | Publisher Full Text

49. Parida M, Sannarangaiah S, Dash PK, et al.: Loop mediated isotherma amplification (LAMP): a new generation of innovative gene amplification technique; perspectives in clinical diagnosis of infectious diseases. Rev Med Virol. 2008; 18(6): 407-21. PubMed Abstract | Publisher Full Text | Free Full Text

50. Poon LLM, Leung CSW, Chan KH, et al.: Detection of human influenza A viruses by loop-mediated isothermal amplification. / Clin Microbiol. 2005; 43(1): 427-30.

PubMed Abstract | Publisher Full Text | Free Full Text

51. Iwamoto $T$, Sonobe $T$, Hayashi K: Loop-mediated isothermal amplification for direct detection of Mycobacterium tuberculosis complex, M. avium, and M. intracellulare. in sputum samples. J Clin Microbiol. 2003; 41(6): 2616-22. PubMed Abstract | Publisher Full Text | Free Full Text

52. Becherer L, Bakheit M, Frischmann S, et al.: Simplified Real-Time Multiplex Detection of Loop-Mediated Isothermal Amplification Using Novel Mediator Displacement Probes with Universal Reporters. Anal Chem. 2018; 90(7): 4741-8.

PubMed Abstract | Publisher Full Text

53. Seidel $M$, Niessner R: Automated analytical microarrays: a critical review. Anal Bioanal Chem. 2008; 391(5): 1521-44. PubMed Abstract | Publisher Full Text | Free Full Text

54. Schulze A, Downward J: Navigating gene expression using microarrays-a technology review. Nat Cell Biol. 2001; 3(8): E190-5.

PubMed Abstract | Publisher Full Text

55. Park S, Gildersleeve JC, Blixt O, et al.: Carbohydrate microarrays. Chem Soc Rev. 2013; 42(10): 4310-26. PubMed Abstract | Publisher Full Text | Free Full Text

56. Carmona SJ, Sartor PA, Leguizamón MS, et al.: Diagnostic peptide discovery: prioritization of pathogen diagnostic markers using multiple features. PLoS One. 2012; 7(12): e50748.

PubMed Abstract | Publisher Full Text | Free Full Text

57. List C, Qi W, Maag E, et al.: Serodiagnosis of Echinococcus spp. infection: explorative selection of diagnostic antigens by peptide microarray. PLOS Negl Trop Dis. 2010; 4(8): e771.

PubMed Abstract | Publisher Full Text | Free Full Text

58. Gardner TJ, Stein KR, Duty JA, et al: Functional screening for anti-CMV biologics identifies a broadly neutralizing epitope of an essential envelope protein. Nat Commun. 2016; 7: 13627. PubMed Abstract | Publisher Full Text | Free Full Text

59. Nixon CE, Park S, Pond-Tor S, et al.: Identification of protective B-cel epitopes within the novel malaria vaccine candidate Plasmodium falciparum schizont egress antigen 1. Clin Vaccine Immunol. 2017; 24(7): e00068-17.

PubMed Abstract | Publisher Full Text | Free Full Text

60. Khairy WO, Qian K, Shao H, et al.: Identification of two conserved B-cell epitopes in the gp90 of reticuloendothelial virus using peptide microarray. Vet Microbiol. 2017; 211: 107-11.

PubMed Abstract | Publisher Full Text

61. Davies $\mathrm{DH}$, Liang $\mathrm{X}$, Hernandez JE, et al.: Profiling the humoral immune response to infection by using proteome microarrays: high-throughput vaccine and diagnostic antigen discovery. Proc Natl Acad Sci U S A. 2005: 102(3): 547-52.

PubMed Abstract | Publisher Full Text | Free Full Text

62. Legutki JB, Zhao ZG, Greving M, et al.: Scalable high-density peptide arrays for comprehensive health monitoring. Nat Commun. 2014: 5: 4785. PubMed Abstract | Publisher Full Text

63. Disney MD, Seeberger PH: The Use of Carbohydrate Microarrays to Study Carbohydrate-Cell Interactions and to Detect Pathogens. Chem Biol. 2004; 11(12): 1701-7.

PubMed Abstract | Publisher Full Text

64. Wang D: Carbohydrate microarrays. Proteomics. 2003; 3(11): 2167-75. Publisher Full Text

65. Uttamchandani M, Neo JL, Ong BNZ, et al.: Applications of microarrays in pathogen detection and biodefence. Trends Biotechnol. 2009; 27(1): 53-61. PubMed Abstract | Publisher Full Text | Free Full Text

66. Delaney SR, Suh-Lailam BB: Microfluidics: The future of testing? Clinical Chemistry. 2018; 64(2): 417. Publisher Full Text

67. Whitesides GM: The origins and the future of microfluidics. Nature. 2006; 442(7101): 368-73.

PubMed Abstract | Publisher Full Text
68. Sekhon BS, Kamboj S: Microfluidics technology for drug discovery and development-an overview. Int J Pharm Tech Res. 2010; 2(1): 804-9. Reference Source

69. Bleidorn C: Third generation sequencing: technology and its potential impact on evolutionary biodiversity research. Syst Biodivers. 2015; 14(1): 1-8. Publisher Full Text

70. Bayley $\mathrm{H}$ : Nanopore sequencing: from imagination to reality. Clin Chem. 2015; 61(1): 25-31.

PubMed Abstract | Publisher Full Text | Free Full Text

71. Derrington IM, Butler TZ, Collins MD, et al.: Nanopore DNA sequencing with MspA. Proc Natl Acad Sci U S A. 2010; 107(37): 16060-5. PubMed Abstract | Publisher Full Text | Free Full Text

72. L Liang L, Wang Q, Ågren $\mathrm{H}$, et al.: Computational studies of DNA sequencing with solid-state nanopores: key issues and future prospects. Front Chem. 2014; $2: 5$.

PubMed Abstract | Publisher Full Text | Free Full Text

73. Brenner BG, Roger M, Routy JP, et al.: High rates of forward transmission events after acute/early HIV-1 infection. J Infect Dis. 2007; 195(7): 951-9. PubMed Abstract | Publisher Full Text

74. Wood CS, Thomas MR, Budd J, et al.: Taking connected mobile-health diagnostics of infectious diseases to the field. Nature. 2019; 566(7745): 467-74.

PubMed Abstract | Publisher Full Text | Free Full Text

75. Takahashi S, Machikawa F, Noda A, et al.: Detection of immunoglobulin G and $A$ antibodies to rubella virus in urine and antibody responses to vaccineinduced infection. Clin Diagn Lab Immunol. 1998; 5(1): 24-7. PubMed Abstract | Publisher Full Text | Free Full Text

76. Wang K, Lee I, Carlson G, et al:: Systems biology and the discovery of diagnostic biomarkers. Dis Markers. 2010; 28(4): 199-207. PubMed Abstract | Publisher Full Text | Free Full Text

77. Guo L, Ren L, Yang S, et al.: Profiling Early Humoral Response to Diagnose Novel Coronavirus Disease (COVID-19). Clin Infect Dis. 2020; 71(15): 778-785. PubMed Abstract | Publisher Full Text | Free Full Text

78. Muñoz JAM, Chenoll E, Casinos B, et al.: Novel probiotic Bifidobacterium longum subsp. infantis CECT 7210 strain active against rotavirus infections. Appl Environ Microbiol. 2011; 77(24): 8775-83.

PubMed Abstract | Publisher Full Text | Free Full Text

79. Zmora N, Bashiardes S, Levy $M$, et al.: The role of the immune system in metabolic health and disease. Cell Metab. 2017; 25(3): 506-21. PubMed Abstract | Publisher Full Text

80. Almansa R, Wain J, Tamayo $E$, et al.: Immunological monitoring to prevent and treat sepsis. Crit Care. 2013; 17(1): 109. PubMed Abstract | Publisher Full Text | Free Full Text

81. Huffnagle GB, Noverr MC: The emerging world of the fungal microbiome. Trends Microbiol. 2013: 21(7): 334-41.

PubMed Abstract | Publisher Full Text | Free Full Text

82. Monaco CL, Gootenberg DB, Zhao G, et al.: Altered virome and bacterial microbiome in human immunodeficiency virus-associated acquired immunodeficiency syndrome. Cell Host Microbe. 2016; 19(3): 311-22. PubMed Abstract | Publisher Full Text | Free Full Text

83. Zevin AS, McKinnon L, Burgener A, et al.: Microbial translocation and microbiome dysbiosis in HIV-associated immune activation. Curr Opin HIV AIDS. 2016; 11(2): 182-90.

PubMed Abstract | Publisher Full Text | Free Full Text

84. Lynch SV, Pedersen O: The human intestinal microbiome in health and disease. N Engl] Med. 2016; 375(24): 2369-79. PubMed Abstract | Publisher Full Text

85. Pannaraj PS, Li F, Cerini C, et al.: Association between breast milk bacterial communities and establishment and development of the infant gut microbiome. JAMA Pediatr. 2017; 171(7): 647-54. PubMed Abstract | Publisher Full Text | Free Full Text

86. $\mathrm{Lu} \mathrm{CY}, \mathrm{Ni} \mathrm{YH}$ : Gut microbiota and the development of pediatric diseases. J Gastroenterol. 2015; 50(7): 720-6.

PubMed Abstract | Publisher Full Text

87. Bischoff SC, Barbara G, Buurman W, et al.: Intestinal permeability--a new target for disease prevention and therapy. BMC Gastroenterol. 2014; 14(1): 189.

PubMed Abstract | Publisher Full Text | Free Full Text

88. Drakesmith $\mathrm{H}$, Prentice AM: Hepcidin and the iron-infection axis. Science. 2012; 338(6108): 768-72.

PubMed Abstract | Publisher Full Text

89. Cassat JE, Skaar EP: Iron in infection and immunity. Cell Host Microbe. 2013; 13(5): 509-19.

PubMed Abstract | Publisher Full Text | Free Full Text

90. Spottiswoode N, Duffy PE, Drakesmith H: Iron, anemia and hepcidin in malaria. Front Pharmacol. 2014; 5: 125. PubMed Abstract | Publisher Full Text | Free Full Text

91. Armitage AE, Stacey AR, Giannoulatou $E$, et al.: Distinct patterns of hepcidin and iron regulation during $\mathrm{HIV}-1, \mathrm{HBV}$, and $\mathrm{HCV}$ infections. Proc Natl Acad SCi U S A. 2014; 111(33): 12187-92.

PubMed Abstract | Publisher Full Text | Free Full Text

92. Chenoll E, Casinos B, Bataller E, et al.: Novel probiotic Bifidobacterium bifidum 
CECT 7366 strain active against the pathogenic bacterium Helicobacter pylori. Appl Environ Microbiol. 2011; 77(4): 1335-43.

PubMed Abstract | Publisher Full Text | Free Full Text

93. Boulangé $\mathrm{CL}$, Neves $\mathrm{AL}$, Chilloux J, et al.: Impact of the gut microbiota on inflammation, obesity, and metabolic disease. Genome Med. 2016; 8(1): 42.

PubMed Abstract | Publisher Full Text | Free Full Text

94. Sonnenburg ED, Sonnenburg JL: Starving our microbial self: the deleterious consequences of a diet deficient in microbiota-accessible carbohydrates. Cell Metab. 2014; 20(5): 779-86.

PubMed Abstract | Publisher Full Text | Free Full Text

95. Organization WH: Laboratory testing for coronavirus disease (COVID-19) in suspected human cases: interim guidance, 19 March 2020. World Health Organization; 2020.

Reference Source

96. Udugama B, Kadhiresan P, Kozlowski HN, et al.: Diagnosing CoviD-19: The Disease and Tools for Detection. ACS Nano. 2020; 14(4): 3822-35. PubMed Abstract | Publisher Full Text | Free Full Text

97. Long QX, Liu BZ, Deng $\mathrm{H}$, et al: Antibody responses to SARS-CoV-2 in patients with COVID-19. Nat Med. 2020; 26(6): 845-848. PubMed Abstract | Publisher Full Text

98. Tang YW, Schmitz JE, Persing DH, et al.: Laboratory Diagnosis of COVID-19:
Current Issues and Challenges. J Clin Microbiol. 2020; 58(6): e00512-20. PubMed Abstract | Publisher Full Text | Free Full Text

99. Eden E, Srugo I, Gottlieb T, et al.: Diagnostic accuracy of a TRAIL, IP-10 and CRP combination for discriminating bacterial and viral etiologies at the Emergency Department. J Infect. 2016; 73(2): 177-80. PubMed Abstract | Publisher Full Text

100. van Houten CB, de Groot JA, Klein A, et al.: A host-protein based assay to differentiate between bacterial and viral infections in preschool children (OPPORTUNITY): a double-blind, multicentre, validation study. Lancet Infect Dis. 2017; 17(4): 431-40.

PubMed Abstract | Publisher Full Text

101. Kirigia JM, Barry SP: Health challenges in Africa and the way forward. Int Arch Med. BioMed Central; 2008; 1(1): 27. PubMed Abstract | Publisher Full Text | Free Full Text

102. Eamudomkarn C, Sithithaworn P, Kamamia C, et al.: Diagnostic performance of urinary IgG antibody detection: A novel approach for population screening of strongyloidiasis. PLoS One. 2018; 13(7): e0192598. PubMed Abstract | Publisher Full Text | Free Full Text

103. Organization WH: Report of the first meeting of the WHO diagnostic technical advisory group for neglected tropical diseases. Geneva, Switzerland. October 2019. 2020; 30-31.

Reference Source 


\section{Open Peer Review}

\section{Current Peer Review Status: ?}

\section{Version 1}

Reviewer Report 01 October 2021

https://doi.org/10.21956/aasopenres.14355.r28882

(C) 2021 Schoepp R. This is an open access peer review report distributed under the terms of the Creative Commons Attribution License, which permits unrestricted use, distribution, and reproduction in any medium, provided the original work is properly cited.

\section{Randal J. Schoepp}

Diagnostic Systems Division, United States Army Medical Research Institute of Infectious Diseases, Frederick, MD, USA

The authors have written a review of the current diagnostic methods, both antibody and nucleicacid based assays and the challenge of implementation in resource limited regions in Africa. While the title reflects their intent, I feel that the manuscript does not. The authors review the current state of the art of modern-day diagnostics, however there is very little discussion of the substantial efforts and obstacles to the implementation in these resource poor settings. They point out some of the problems, but do not really convey to the reader the significant shortfalls in staff training and education, infrastructure challenges, and sustainment requirements. Much of the technology suggested is far too expensive or complex for rural or urban settings in many of the countries intended. The state of the art is presented well but is too brief in a discussion of the nuances as they relate to the technology and use in resource limited settings. The majority of the authors' suggestions of needed technology is accurate, but the difficulty of implementation is glossed over. This review would be better served if they discussed the needs of the resource challenged settings and what would be possible at this time with the current technology and the available infrastructure. The improvements needed to implement more advanced technologies and the benefits they would have would be a more logical course. Many of the technologies that are presented have problems in developed countries and would be next to impossible in most settings in Africa, for instance biomarkers or diagnostic sequencing. For those of us that work in these settings, the authors' suggestions are the ideals in a perfect world where developed countries raise up the technological capabilities in developing countries, but in reality a rapid malaria test, a few ELISAs, and maybe the ability to do PCR is a challenge in resource limited settings.

Specific edits:

Pg 1, Abstract: The use of the word "trialled" is awkward, consider "developed".

Pg 3, Table 1: Monkeypox virus line, Cameroon is misspelled.

Pg 4, $2^{\text {nd }} \mathrm{col}, 2^{\text {nd }}$ parag: The use of the word "checks" makes little sense. 
Pg 5, Table 2: Culture-based.... Limitations should include "can require biocontainment; not field deployable; long processing time.

Pg 5, Table 2: Immunodiagnostic assays: Limitations.... Does not require only monoclonal antibodies, many tests use polyclonals also. No mention of IgM vs IgG detection.

Pg 6, 2nd col, 3rd parag: The use of the word "trialled" is awkward, consider "developed".

Pg 7, $1^{\text {st }}$ col, $1^{\text {st }}$ parag: RT-PCR does NOT detect only viable pathogens, there are many instances of positive RT-PCR results, but there is no live virus present.

Pg 7, 1st col, 2nd parag: Important to note that probes add specificity, which can allow for single spps specificity.

Pg 7, Underlying Science.... Section: the majority of the technology presented in far beyond resource limited settings.

Pg 11, Table 3, Limitations, Antigen-based: requires "antibodies" not just monoclonals.

Is the topic of the review discussed comprehensively in the context of the current literature?

Yes

Are all factual statements correct and adequately supported by citations?

Yes

Is the review written in accessible language?

Yes

Are the conclusions drawn appropriate in the context of the current research literature? Partly

Competing Interests: No competing interests were disclosed.

Reviewer Expertise: Virology, Diagnostics, arthropod-borne viruses, hemorrhagic fever viruses

I confirm that I have read this submission and believe that I have an appropriate level of expertise to confirm that it is of an acceptable scientific standard, however I have significant reservations, as outlined above. 